\title{
Black Leaf Streak Disease is challenging the banana industry
}

\author{
Luc de Lapeyre DE BellaiRE ${ }^{1 *}$, Eric FourÉ ${ }^{1}$, Catherine ABAdIE ${ }^{2,3}$, Jean CARLIER ${ }^{2}$
}

${ }^{1}$ CIRAD-Persyst, UPR Systèmes bananes et ananas, TA B-26 / PS4, Blvd. de la Lironde, 34398 Montpellier Cedex 5, France, luc.de_lapeyre_de_bellaire@ cirad.fr

2 CIRAD-Bios, UMR BGPI, Campus international de Baillarguet, TA A-54 / K, 34398 Montpellier Cedex 5, France

${ }^{3}$ CIRAD-Bios, UPR Multiplication végétative, Station de Neufchâteau, Sainte-Marie, 97130 Capesterre-Belle-Eau, Guadeloupe, France
${ }^{*}$ Correspondence and reprints

Received 30 August 2010 Accepted 15 September 2010

Fruits, 2010, vol. 65, p. 327-342 (C) 2010 Cirad/EDP Sciences All rights reserved DOI: $10.1051 /$ fruits/2010034 www.fruits-journal.org

RESUMEN ESPAÑOL, p. 342
Black Leaf Streak Disease is challenging the banana industry.

Abstract - Introduction. Black Leaf Streak Disease (BLSD) is regarded as the most economically important threat that the banana industry has to face. Effectively, this foliar disease affects leaf photosynthesis but, above all, reduces the greenlife of fruits, that cannot be exported in cases of severe infestation. Main characteristics of Black Leaf Streak Disease. More than 20 Mycosphaerella species have been described on bananas. Leaf spot diseases of bananas are caused by some species of this complex, of which M. fijiensis (BLSD) and M. musicola (Sigatoka disease) are the most important. $M$. fijiensis is an invasive species that has totally replaced $M$. musicola in most banana-exporting countries, which was conducive to increasing difficulties in banana leaf spot control. BLSD causes increasing difficulties for control. Since all banana cultivars grown in the banana industry are highly susceptible to BLSD, the control of this disease relies on aerial applications of fungicides according to either systematic frameworks (mostly contact fungicides) or forecasting strategies (mostly systemic fungicides). In a banana-exporting country where M. fijiensis has been reported, BLSD control becomes increasingly more difficult. This evolution is essentially due to the rapid emergence of fungicide resistance, and is conducive to a significant increase in the cost of disease control but, above all, to increasing negative environmental effects. Challenges for the banana industry. Because of the rapid adaptation of $M$. fijiensis, the banana industry must be prepared for significant evolution. We propose various parameters that should be monitored at different levels (disease assessment parameters, evaluation of chemical control efficiency, global evaluation of BLSD economic incidence) to rationalize such evolution. The modelization of BLSD effects on bunch mass and greenlife should enable defining acceptable disease thresholds and optimizing bunch weight and harvest stage according to agronomic practices. On the other hand, fungicide use is conducive to significant environmental impact and must be limited. Forecasting strategies should be used wherever systemic fungicides are still efficient. Finally, the predominance of a unique type of susceptible cultivar is unsustainable and the recourse to resistant varieties in an integrated strategy is undoubtedly the future of BLSD control. France / Musa / disease control / fungal diseases / Mycospbaerella fijiensis / resistance to chemicals

\section{La Maladie des Raies Noires défie l'industrie de la banane.}

Résumé - Introduction. La Maladie des Raies Noires (MRN) est la plus grande menace à laquelle est confrontée l'industrie de la banane. En effet, cette maladie foliaire affecte la photosynthèse des bananiers mais, surtout, elle entraine une réduction du potentiel de conservation des fruits qui ne peuvent être exportés lorsque les bananiers sont sévèrement atteints. Principales caractéristiques de la MRN. Plus de 20 espèces du genre Mycosphaerella ont été décrites sur le bananier, mais les cercosporioses des bananiers sont principalement le fait de deux espèces $M$. fijiensis (MRN) et $M$. musicola (maladie de Sigatoka). M. fijiensis est une espèce invasive qui a totalement remplacé $M$. musicola dans la plupart des pays exportateurs de bananes, ce qui s'est toujours traduit par un contrôle plus difficile de la cercosporiose. Des difficultés de contrôle croissantes. Comme toutes les variétés de bananes cultivées dans l'industrie de la banane sont très sensibles aux cercosporioses, le contrôle de la MRN repose sur l'application aérienne de fongicides soit selon des programmes systématiques (fongicides de contact), soit sur avertissement (fongicides systémiques). Dans les pays exportateurs de bananes où $M$. fijiensis a été détecté, le contrôle de la MRN est devenu de plus en plus difficile. Cette évolution a principalement été le fait de l'apparition de souches résistantes aux fongicides et s'est traduite par une augmentation du coût de la lutte et surtout par un accroissement des impacts environnementaux. Des défis pour l'industrie bananière. Comme M. fijiensis a des capacités d'adaptation très rapides, une des conditions de survie de l'industrie bananière est de se préparer à d'importantes mutations. Nous proposons une batterie d'indicateurs à différents niveaux (parcelle, efficacité globale de la lutte, incidence économique globale) afin d'objectiver ces évolutions. La modélisation des effets de la MRN sur le poids des régimes et la durée de conservation des fruits devrait permettre de définir des niveaux de maladie acceptables mais aussi d'optimiser le poids des régimes et le stade de récolte en fonction des pratiques agronomiques. Afin de limiter l'emploi des fongicides qui ont un impact environnemental important, les stratégies d'avertissement doivent être employées partout où les fongicides systémiques sont encore efficaces. Enfin, la prédominance de cultivars sensibles n'est pas durable et le futur de cette industrie passe probablement par l'incorporation dans les systèmes de culture de variétés résistantes.

France / Musa / contrôle de maladies / maladie fongique / Mycosphaerella fijiensis / résistance aux produits chimiques 


\section{Introduction}

Bananas are one of the main agricultural productions in the world, and the main fruit crop, with an annual production of about $110 \mathrm{Mt}$ [1]. International trade of bananas represents $14 \mathrm{Mt} \cdot \mathrm{year}^{-1}$ with a value of more than 4 billion US $\$$ [2]. The production of bananas for this international trade is grown in a small number of tropical countries mainly located in Latin America (80\%), in African and Asian countries, and in the European community (French West Indies, Canary Islands). In all these countries, this industry is economically important and a source of direct and indirect employment. In the world of the banana industry, Black Leaf Streak Disease (BLSD) is regarded as the most economically important disease [3] and is considered as one of the most important crop diseases in the world [4]. This situation is mainly because the banana trade relies on a unique banana group of cultivars (Musa acuminata, AAA, Cavendish subgroup) which are highly susceptible to this disease. The dominance of the Cavendish cultivars results itself from the organization of the banana production in an industry which is furthermore (i) highly concentrated in multinational groups [2], and (ii) characterized by the presence of an industrial process at the end of the chain since bananas are artificially ripened in industrial ripening houses before marketing.

Black Leaf Streak Disease of bananas is a foliar disease. The first symptoms of this disease are reddish-brown streaks $(<1 \mathrm{~mm})$ which enlarge and can form lesions of up to $20-30 \mathrm{~mm}$, becoming darker in color [5] This leaf spotting has two kinds of effects on the banana yield. Since BLSD affects the photosynthetic area of banana leaves, the production of dry matter is reduced by leaf spotting. It has been shown for Sigatoka Disease (SD), a related Mycosphaerella foliar disease of bananas, that the diminution of the leaf area, induced by severe spotting, had a strong effect on bunch weight [6]. For BLSD, significant yield losses (20\% to 50\%) were also estimated on plantains [7, 8]. However, another important component of banana yield is the fruit aptitude for conservation. Effectively, banana is a climacteric fruit [9], harvested still green at a pre-climacteric stage before being ripened artificially with ethylene in ripening rooms. The time between harvest and the climacteric rise is called the greenlife and reflects the potential of fruit conservation [10], which should be superior to the time between harvest and artificial ripening. The main effect of BLSD is the reduction of the greenlife of harvested fruits on heavily diseased plants [11]. This is why this disease is such a significant threat to the banana industry. Effectively, banana growers must control BLSD to a level that does not alter fruit exportation. This is why the different banana companies generally perform a systematic control of this disease and use an empiric threshold of remaining leaves at harvest (3-5 leaves according to the companies) in order to decide which bunches are exportable or not. The economic incidence of this disease is significant since the cost of control can reach more than $25 \%$ of the production cost [12]. BLSD incidence in the banana industry is regularly increasing and the objective of our paper is to highlight the origin of these variations and to propose some evolution in the banana industry, driven by research, in order to prevent a new 'crisis' in this industry.

\section{Main characteristics of Black Leaf Streak Disease}

\subsection{A fungal pathogen within a complex of species}

BLSD is caused by an ascomycetous heterothallic fungus, Mycosphaerella fijiensis Morelet, which was first described in the island of Fiji in 1963 [13]. Mycosphaerella fijiensis produces bicellular ascospores while its anamorph Paracercospora fijiensis forms 1-10 septate conidia which are produced singly at the apex of conidiophores. Sigatoka Disease, caused by Mycosphaerella musicola (anamorph Pseudocercospora musae), was the first Mycosphaerella foliar disease of bananas described in Java in 1902 [14]. The two fungi can only be distinguished by the morphology of their anamorph [15]. More recently, a third 
Mycosphaerella foliar disease of bananas (Mycosphaerella eumusae, anamorph Pseudocercospora eumusae) was reported in Southern and Southeast Asia [16]. Later, a broad study revealed that more than 20 Mycosphaerella species can be isolated from banana leaves [17], but, except for Mycosphaerella musae causing a leaf freckle, the implication of these other Mycosphaerella species as leaf pathogens of bananas has not been determined. Molecular diagnostic tools have been developed from specific actin or beta-tubulin genes [18] or ITS sequences [19] to distinguish M. fijiensis, M. musicola and M. eumusae, but these tools should take into account this broader complex. On the other hand, the potential implication of these species as new foliar diseases either on Cavendish, or on other banana cultivars is questionable. The predominance of $M$. eumusae in some Asiatic countries suggests a differential adaptation of the different Mycosphaerella species and the competitiveness between these species should be better understood.

\subsection{Main considerations on the life cycle of BLSD}

The life cycle of BLSD has been widely described [3, 11] and starts with leaf infection by either ascospores or conidia. After a period of epiphyllic growth of generally 2-3 days, germ tubes penetrate stomata. In good conditions, the first symptoms appear generally 10-14 days after. The symptoms then gradually evolve from stage 1 to stage 6. Conidia are produced on young stages of the disease (stage 2-4) and have been considered as water dispersed at short distances, even if they are also present in the airspora [20]. Ascospores are produced at the later stage and are wind-dispersed after perithecia burst. They are considered to be dispersed at longer distances than conidia [21].

It is important to highlight some characteristics of this life cycle that are useful for BLSD control.

\subsubsection{Infection starts in young leaves}

Because of antagonism on old leaves, infection mainly occurs on the cigar and the first unfurled leaf. Therefore, there is a gradient of evolution of the disease from the top to the bottom of the banana tree, and fungicide applications should be aimed at the top of banana trees to control new infections. New attacks should be detected only on young leaves, which is particularly important for disease monitoring in forecasting strategies.

\subsubsection{The duration of the incubation period is variable}

The duration of the incubation period, as well as the symptom evolution time, is very variable according to climatic variations. This indicates a real possibility for forecasting systems to work where climatic conditions might be unfavorable to disease development.

\subsubsection{Ascospores are produced in late stages}

Although the epidemiological importance of conidia is still not well understood, it is accepted that ascospores are predominant in BLSD epidemiology. Therefore, in order to control field inoculum, it is essential to control the disease before necrotic formation. Where leaves are heavily spotted, they should be removed, since they might produce ascospores for many months.

\subsubsection{Inoculum is wind-dispersed}

As wind-transported ascospores can disseminate the disease over long distances, BLSD has a strong potential progression in landscapes where Musa genotypes are quite frequent, which is the case in most tropical countries where bananas are grown. Control of the disease should be maintained by all growers of one region, using the same technical guidelines because disease and pathogen evolution in a specific geographic area has potential influence over a wider area.

\subsection{BLSD, a disease still in worldwide expansion}

At the beginning of the banana industry, Sigatoka Disease was present in all countries located in tropical humid conditions and the control of this disease was easier and less 
expensive than for BLSD. In all countries where $M$. fijiensis has been reported, this pathogen rapidly replaced $M$. musicola. The economic consequences of the emergence of BLSD in such countries were very significant, and the case of the expansion of this pathogen in Latin America showed various significant effects such as (i) significant losses due to premature ripening, (ii) significant increases in production costs, and (iii) the abandoning of significant commercial areas for exportation and for plantain production [22]. M. fijiensis is more aggressive than M. musicola, and particularly on plantains [23], which are an important food crop in many countries and particularly in Africa and Latin America. Since the aggressiveness of $M$. musicola is very low on plantains, growers were not prepared for leaf spot disease control, and the emergence of BLSD on this food crop had a dramatic incidence, leading to significant crop losses and to the abandoning of significant commercial areas [22]. However, in the ecological conditions of highlands (Cameroon, Colombia), M. musicola was pathogenic on plantains [24] and the substitution of M. musicola by M. fijiensis has been delayed [25].

The genetic structure of $M$. fijiensis populations around the world shows that this fungus originated from South-East Asia and has been brought to other continents through limited introductions due to germplasm transportation [26]. From the original center, two recent and rapid continental expansions have occurred and are still in progress. The most important for the banana industry started in the American continent from Honduras in 1972 [3, 27]. Progressively all central American countries have been colonized, and tropical and subtropical South American and North American countries were also colonized (figure 1). This expansion is still in progress in the Caribbean islands from a first northern introduction in Cuba in 1990 and a probable southern independent introduction in Trinidad in 2003. Only a few islands, including Martinique, Dominica and Guadeloupe, remain free of BLSD, the most recent report being in St-Vincent and Ste-Lucia in 2009 and 2010, where its expansion has been very fast. The second continental expansion has been in the African continent, probably from a hypothetical initial introduction in Zambia in 1973 [3, 27]. In Cameroon, BLSD was reported in 1980 and totally replaced Sigatoka disease in the commercial banana farms in less than 2 years. Population structure analysis of $M$. fijiensis from the global to local scales have allowed us to understand better the dispersal processes underlying this recent pandemic [26, 28, 29]. Particularly, founder effects were detected in the global population structure of M.fijiensis, suggesting rare migration events among continents through movements of infected plant material.

Depending on environmental conditions, BLSD may have a rapid geographic expansion, mainly because ascospores can be wind-transported over long distances. Therefore, $M$. fijiensis is a quarantine organism in all countries where this disease is not present, the best control method being the prevention of its introduction. Specific control measures were therefore established to prevent the dissemination of this disease to new countries [30]. These measures include: (i) specific communication to the population; (ii) coordination of sanitary services on a regional scale; (iii) monitoring programs in order to detect the progression of the pathogen, this work being now facilitated by the development of molecular methods $[18,19]$; and (iv) specific legislation to restrict germplasm movement and for obligatory control measures in new infested areas. Once introduced into a new country, BLSD expansion has been fast because bananas are not only grown in industrial plantations, but also in gardens and foodproducing plots. Thus, bananas are scattered regularly in tropical countries, favoring a gradual expansion of the disease. As a consequence, in most countries where BLSD has been introduced, eradication has not been achieved, except in Australia where (i) an intensive surveillance program based on performing diagnostic tests, and (ii) an efficient elimination of infected and neighboring bananas have been implemented [19]. Therefore, chemical control is the only control method that enables BLSD management in all of the banana industry [31]. 


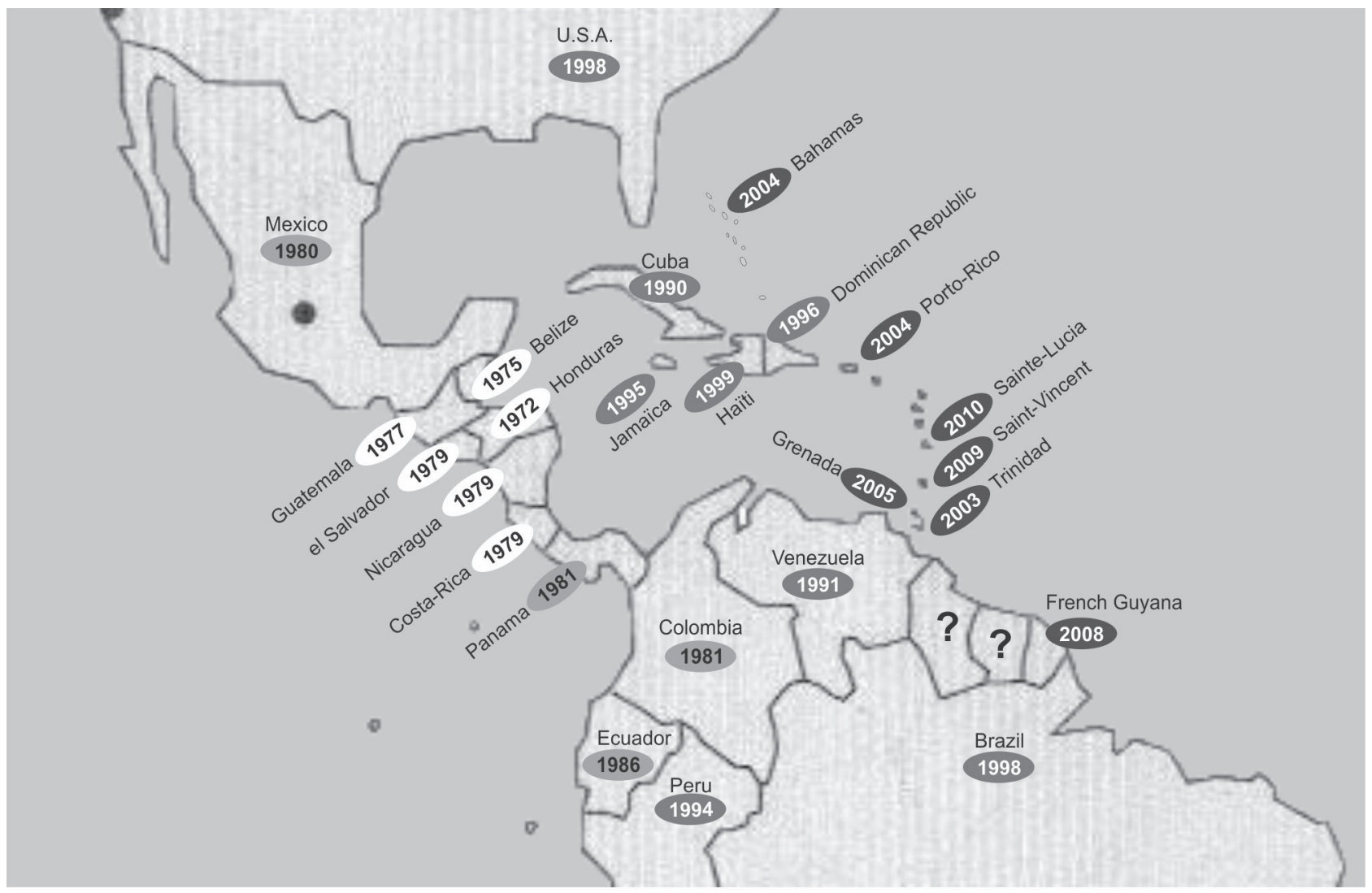

\section{BLSD causes increasing difficulties for control}

In a banana-exporting country where BLSD has been introduced, the history of disease control always shows that control is increasingly more difficult. Then, the number of chemical treatments necessary for disease control increases with time. This is the case in Costa Rica where about 30 fungicide applications per year were realized at the beginning of the 90s [21]. A recent survey of pesticide use carried out in 2007 for the Pesticide Reduction Plan for Banana (PRPB) showed that more than 50 applications per year are now necessary in this country [41]. Another illustration of increasing control difficulties is the case of Cameroon, where BLSD was reported for the first time in 1980. In the banana farms of Cameroon, a forecasting strategy, relying on timing of applications of highly curative systemic fungicides according to biological observations [32], was elaborated and applied with success.
This strategy allowed a significant limitation Figure 1. of chemical use to 12-14 treatments per year. Nevertheless, the development of fungicide resistance led to the progressive Geographic expansion of Black Leaf Streak Disease in the Americas. 
fungicides have been used for BLSD control [31]: contact fungicides and systemic fungicides.

Contact fungicides (mancozeb, chlorothalonil) have only a preventive effect and do not penetrate the banana leaf. They are generally applied every week in systematic frameworks because all new unfurling banana leaves must be protected. They inhibit fungal germination by a multisite action and so do not induce the development of resistant strains.

Systemic fungicides penetrate the banana leaf. The systemic properties of these fungicides are variable: some have only a translaminar transport and others can be distributed in the whole banana plant [35], and the biokinetics of these fungicides confer a more or less pronounced curative effect. The curative effect is more pronounced on young streaks (stages 1,2), but lower on older lesions (stages 3,4) and without any effect on necrotic stages (stages 5, 6), although sporulation might be temporarily decreased. Different chemical families have been used, which are in chronological order: i) antimitotic products that inhibit tubuline polymerization (benzimidazoles); ii) inhibitors of ergosterol biosynthesis that inhibit eburicol demethylation (DMI fungicides mostly belonging to the triazole family); iii) a second group of inhibitors of ergosterol biosynthesis that inhibit several enzymes such as reductases and isomerases (amines); iv) mitochondrial respiration inhibitors that bind to the cytochrome $b$ complex (QoI inhibitors of the strobilurin family); and (v) pyrimethanil, a supposed inhibitor of methionine biosynthesis whose mode of action is still not clearly established. Only systemic fungicides can be used in forecasting systems that rely on early disease detection and a strong curative effect of fungicide applications [36]. For this purpose, systemic fungicides are used in oil mixtures. Nevertheless, since the mode of action of these fungicides is a single target, they provoke the emergence of resistant strains.

Systemic fungicides have been widely used in the banana industry and the development of resistance is frequently reported. This has been the case for benzimidazole products for which the emergence of resistant strains has been very fast in some countries such as Honduras, where they have been reported after only 2-3 years of continuous use [37]. Fungicide resistance to strobilurins has also been very fast in most banana-growing countries, and did not exceed 3 years' use in Costa Rica [38]. A significant shift in the sensitivity to DMI fungicides was also reported in Costa Rica after these fungicides had been used for more than 7 years [39]. After the emergence of resistance, first in a localized area, resistant strains progressively diffuse in most of the banana plantations of the same country [33, 38]. Today, fungicide resistance to benzimidazole and to strobilurins is widespread in the Latin American banana-exporting countries [40]. A similar evolution has been observed in Cameroon where systemic fungicides have been applied in a forecasting strategy [33], although this evolution has been delayed (more than 10 years) in comparison with other areas where systemic fungicides have been used in systematic frameworks. However, fungicide resistance is still not established in some banana plantations of Ivory Coast where systemic fungicides have been used in a forecasting strategy for more than 10 years (de Lapeyre de Bellaire, unpubl. data).

In order to prevent the emergence of fungicide resistance, specific measures should be implemented [40]:

- non-cross-resistant fungicides should be used in alternation in order to limit selection pressure, and particular attention should be paid to the number of applications per year, that should be limited;

- systemic fungicides should not be applied on high population sizes in order to limit the risk of emergence of resistant strains.

Nevertheless, the history of systemic fungicide use in the banana industry shows that these conditions were not fulfilled:

- The first reason is that, in many cases, noncross-resistant fungicides could not be used in alternation because they were not available at the same time. Therefore, in many cases, a new group of fungicides replaced a group that had been discarded because of the emergence of resistant strains. 


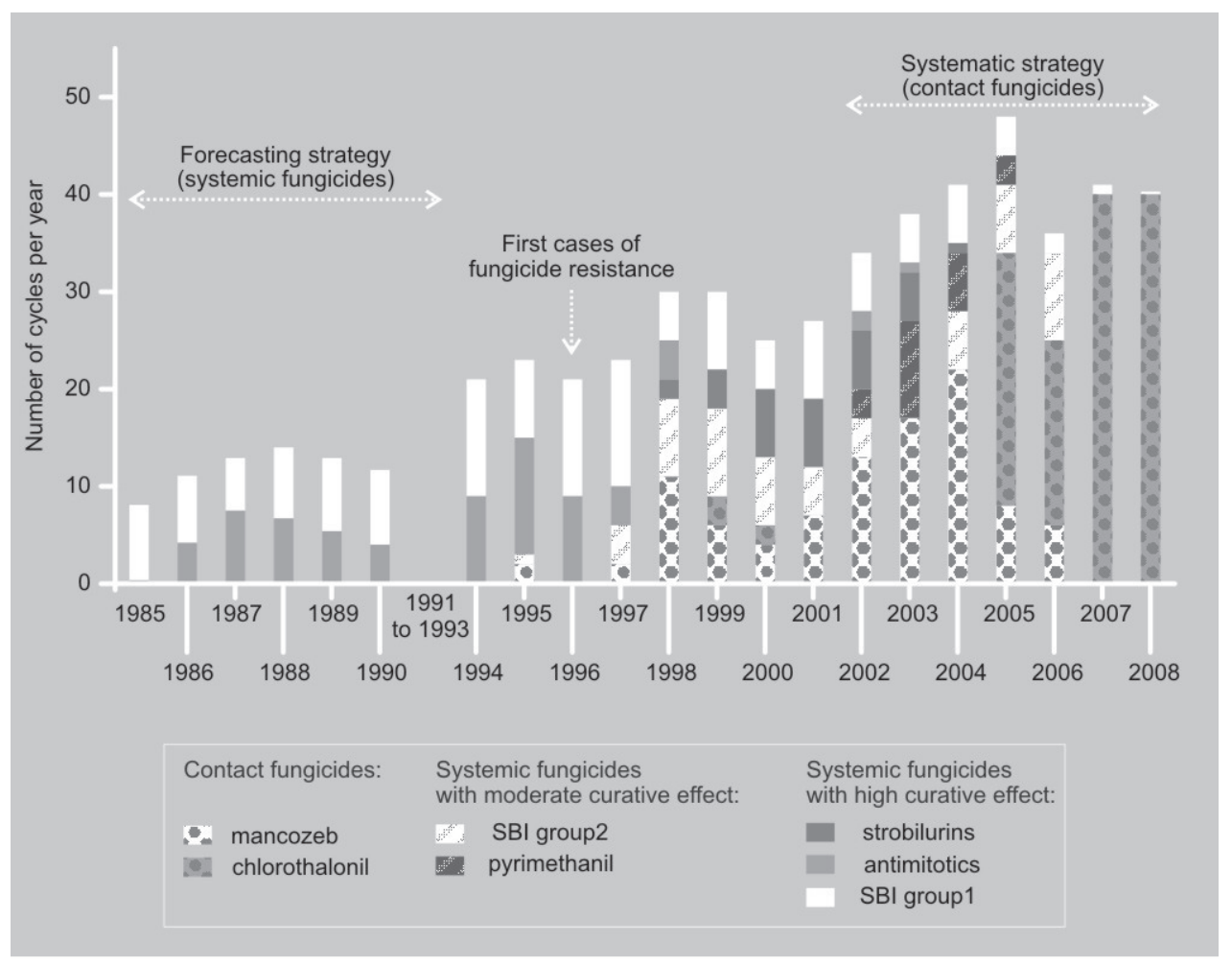

Figure 2.

History of Black Leaf Streak Disease (BLSD) control in banana plantations in Cameroon from 1985 to 2008

- Also, because of their curative effect, systemic fungicides have been intensively used on high population sizes in order to achieve rapid disease control when banana plantations were damaged. This situation has probably accelerated the emergence of fungicide resistance. This has been particularly the case in Cameroon where systemic fungicides were first used in a forecasting strategy (figure 2), reducing the selection pressure. Nevertheless, these fungicides were later used intensively on plantations where control had been lost because of logistic failures and, as a consequence, resistant strains were reported shortly after this period.

- Lastly, the strong dispersion capacity of the pathogen has probably accelerated the diffusion of resistant strains in a production area.

\section{Challenges for the banana industry}

Taking into account the rapid adaptation capacity of $M$. fijiensis, the "battle" against
BLSD will probably never be finished. Therefore, the banana industry must be prepared for significant changes as a condition for its survival. However, increasing difficulties in control will undoubtedly have significant repercussions on the sustainability of chemical control because of increasing environmental incidences and because of the evolution of the legislation in exporting and importing countries driven by consumer demand [33]. Recent studies have shown that, where $M$. fijiensis is present, fungicides for BLSD control represent the most significant contribution to the pesticide use in the banana plantations [41]. Therefore, significant evolution of BLSD control in the future is unavoidable. We present here the evolution that will be needed and the scientific gaps that should be overcome.

\subsection{Elaboration of reliable tools for strategic decisions}

Because changes in control strategies are necessary, it is important to rationalize these evolutions from objective information at different levels. 
Figure 3.

Illustration of the Stage of Evolution of Disease's (SED) potential to monitor the efficiency of the chemical control strategy in banana plantations. All fungicide applications are indicated by an arrow above the SED curve (arrows with different colors correspond to different fungicides applied).

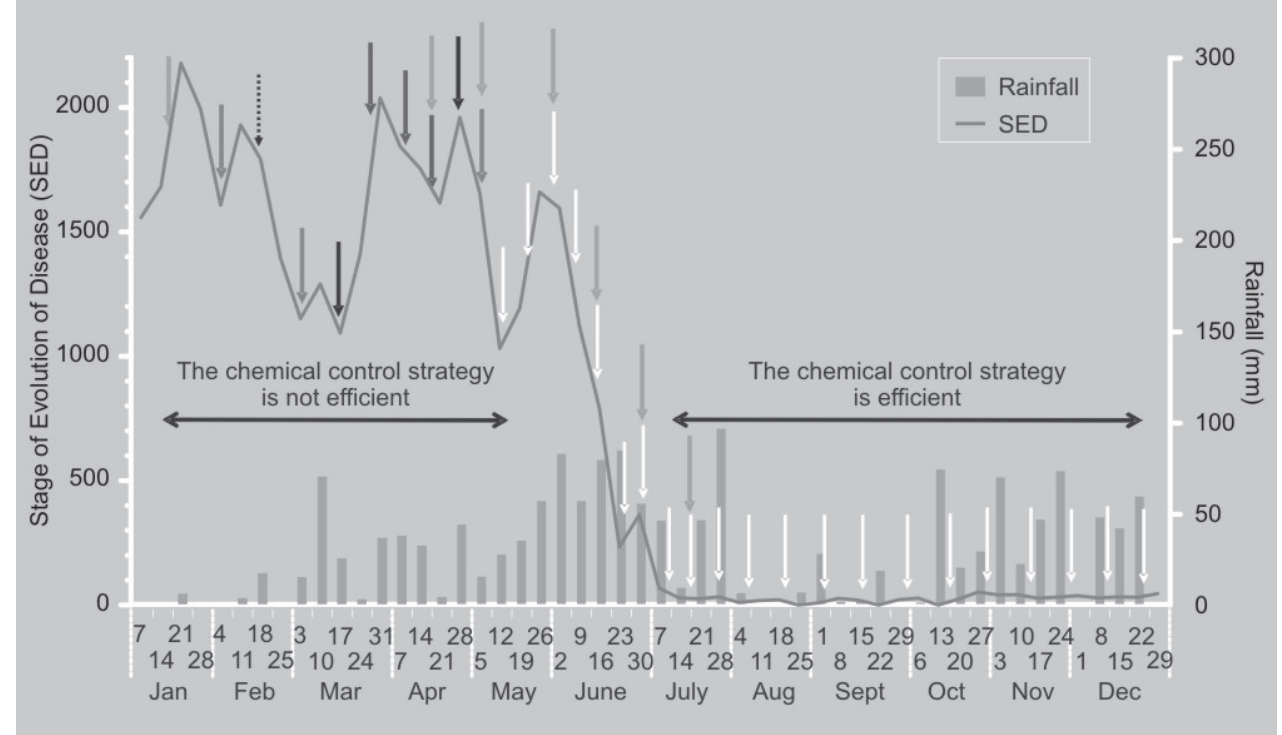

\subsubsection{Disease monitoring at field level}

The first level of elaboration of reliable tools for strategic decisions is to implement a continuous monitoring of disease evolution in the field. It is also informative to fit these weekly data with weekly rainfall, in order to get a better appreciation of epidemiological conditions.

- The Stage of Evolution of Disease, SED, is the main parameter that should be assessed. Disease monitoring methods have mainly been designed for early warning systems and the Stage of Evolution of Disease has been specifically designed for this purpose [36]. Anyway, this parameter is not only useful for timing of decisions, but also to evaluate the efficiency of the chemical control strategy that is designed to reduce disease development on the young banana leaves (figure 3). Therefore, this information should be used whatever the control strategy performed. This assessment is particularly important for systematic strategies in order to detect rapidly any failure in the strategy mainly due to the quality of applications and to inoculum levels.

However, a larger set of disease parameters should also be used. These parameters must be evaluated continuously every week on the same banana plot used for the assessment of SED in order to provide complementary information:
- The 'Youngest Leaf bearing Streaks' (YLSt) is the position of the youngest leaf bearing symptoms of the disease. A value for YLSt must be scored for all banana plants monitored for SED assessment. If none of the 4 leaves monitored have symptoms, the symptoms should be looked for on the older leaves. If none of the leaves bear any symptoms, the value of YLSt will be N+1, where $\mathrm{N}$ is the total number of leaves of the banana tree. The YLSt reflects the incubation period of the disease under a spraying program (figure 4). To interpret this parameter properly it is important to consider that, under a spraying program, the incubation period will depend on both climatic conditions and fungicide inhibition of the pathogen. The progressive evolution of this parameter is thus important to understand the evolution of epidemiological conditions as well as the performance of the chemical strategy in order to protect the youngest leaves, and this information is complementary to the SED.

- The 'Youngest Leaf Spotted' (YLS) should be scored according to Stover's method [42]. In this method, the YLS is the youngest leaf bearing at least 10 necrotic lesions. We propose here new specifications for the assessment of this parameter in order to use this information for a regular diagnosis of the efficiency of the chemical control strategy. Because the absolute value of the YLS 


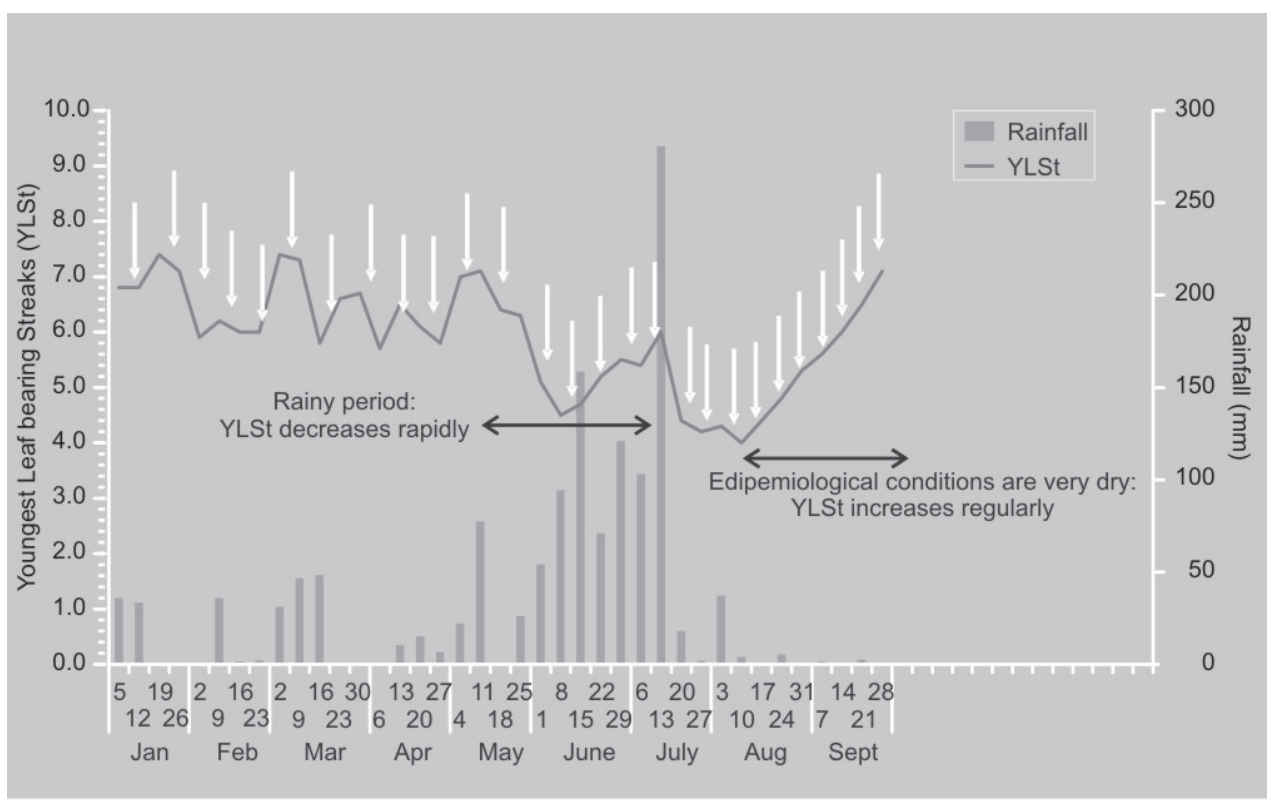

depends on the phenological stage of the banana tree, it is better to consider the weekly evolution of this parameter on the same plants. Effectively, the evolution of the YLS on the same banana plant is a balance between the rate of necrotic formation and the foliar emission rate. Therefore, the evolution of this parameter is helpful to understand the efficiency of the fungicide control at the level of necrotic formation (i.e., at a lower level than SED and YLSt). In order to use this parameter properly, it is important to consider the evolution of the YLS from the establishment of a new plot of 10 plants for SED evaluation up to the flowering of these 10 plants. Then, all these plants should be changed at the same time before flowering and the interpretation of the evolution of the YLS should start again at this stage (figure 5). A value should be scored for each banana tree: if none of the leaves bear any necrotic lesion (this is often the case because of deleafing in banana plantations, so special attention should be paid by workers in order to avoid this), the value of YLS will be $\mathrm{N}+1$, where $\mathrm{N}$ is the total number of leaves of the banana tree. If the YLS is assessed in these conditions, it is possible to interpret its evolution: (i) if the value of YLS decreases, the chemical control is failing because necrotic formation is faster than leaf emission; (ii) if the YLS is increasing, we can conclude that the chemical strategy is efficient in slowing down the necrotic formation (figure 5).

- The 'Number of Functional Leaves at Harvest' (NLH) also has to be evaluated. It is often considered that a functional leaf should have less than $30 \%$ of necrotic surface, although no scientific data support this consideration. The NLH must be evaluated every week on different banana trees and its interpretation is more difficult and imprecise than the other parameters. It is better to make this observation on the same plot used for the other parameters. Generally, in the banana plantations where partial deleafing of infected leaves is performed, NLH is calculated as the sum of different portions of remaining leaves. This parameter is not, in time, directly linked to the chemical applications. Nevertheless, since BLSD mainly mator of how the control strategy has been working and a potential indicator of fruit exportability. Banana companies generally use an empiric threshold of NLH (3-5 according to the companies) in order to decide which bunches are exportable or not. Nevertheless, experimental data do not support this assumption (data not shown) and the value of NLH should be regarded mostly as the efficiency of the chemical strategy at the harvest stage. affects fruit quality, the NLH is the final esti-
Figure 4.

Illustration of Youngest Leaf bearing Streaks (YLSt) variations according to epidemiological conditions and time of chemical treatments applied in banana plantations. All fungicide applications are indicated by an arrow above the YLSt curve. 
Figure 5.

Illustration of interpretation of the Youngest Leaf Spotted (YLS) from its weekly evolution in banana plantations. Arrows indicate the date at which all the 10 banana plants were changed: the value of YLS is artificially different when the banana plants are changed and this variation should not be considered. YLS is scored according to Stover's method [40].

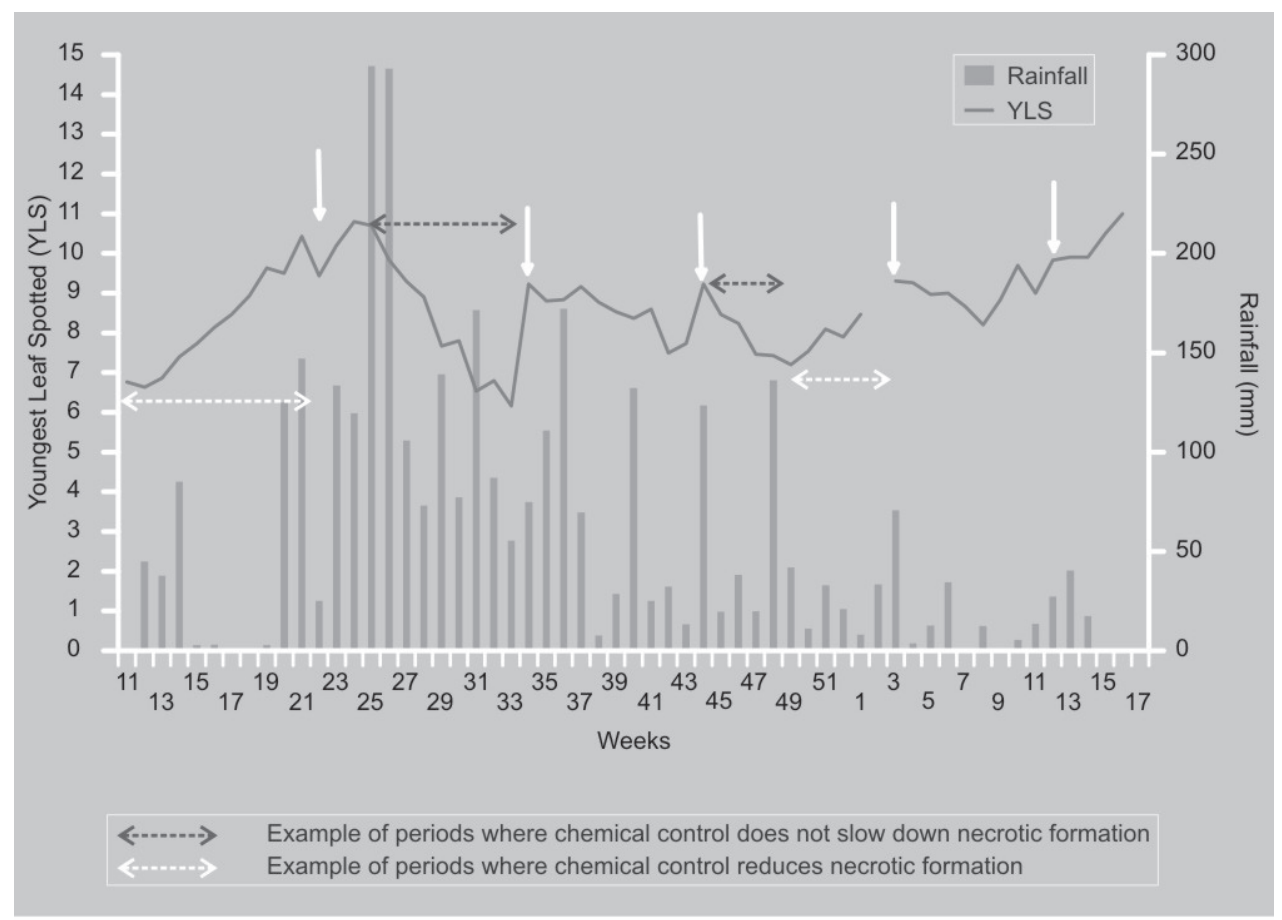

\subsubsection{Global evaluation of the efficiency of the chemical strategy}

The second level of elaboration of reliable tools for strategic decisions is the global efficiency of chemical control. We propose a new indicator to evaluate the efficiency of the chemical control (ECC): $\mathrm{ECC}=\left(\mathrm{SED}_{\mathrm{y}}\right) \times$ $\mathrm{N}_{\mathrm{y}}$, where $\mathrm{SED}_{\mathrm{y}}$ is the average of the weekly values of the SED over one year in a location and $\mathrm{N}_{\mathrm{y}}$ is the number of fungicide treatments applied in one year in this same location

The lower the ECC, the more efficient the chemical control strategy. A low ECC value means that a good control of BLSD is achieved (low average value of SED) with a low number of fungicide treatments. ECC could be an indicator used to monitor the incidence of disease control over time in the same area and could be useful for comparisons between various locations. The variation of the ECC in different situations according to locations with different climates (Ivory Coast, Cameroon or Belize) and according to various types of chemical strategies (forecasting system or systematic strategies) have been calculated (table I). A regular increase in ECC over years means that significant changes should be made in the control strategy. ECC is also interesting for the comparison of various strategies in the same location (table I).

\subsubsection{Global evaluation of economic incidence of BLSD}

The third level of elaboration of reliable tools for strategic decisions is the evaluation of the global economic incidence of BLSD, and there are no existing tools for this purpose. Nevertheless, this evaluation is important because changes in control strategy should be legitimated by a global economic approach. Generally, data on the cost of BLSD control only focus on direct costs for fungicides and fungicide applications. However, this economic impact comprises direct costs (spraying operations, deleafing, etc.), but also indirect costs such as (i) disease monitoring, (ii) losses (bunches rejected, weight reduction, quality reduction), and (iii) the cost of environmental measures [33]. This information should be collected in databases and specific models should be defined in order to simulate the potential benefit of changes in the industry. Only this global approach should justify changes in the industry. 
Table I.

Illustration of the efficiency of the chemical control (ECC) in banana plantations in various situations. $\mathrm{ECC}=\mathrm{SEDy} \times \mathrm{Ny}$, where $\mathrm{SED}_{\mathrm{y}}$ (Stage of Evolution of Disease) is the average of the weekly values of the SED over one year in a location, and $\mathrm{N}_{\mathrm{y}}$ is the number of fungicide treatments applied in one year in this same location SED.

\begin{tabular}{|c|c|c|c|c|c|c|c|}
\hline Zone & Banana plantation & Year & Type of strategy & $\begin{array}{l}\text { Annual rainfall } \\
(\mathrm{mm})\end{array}$ & $\mathrm{SED}_{\mathrm{y}}$ & $\mathrm{N}_{\mathrm{y}}$ & ECC \\
\hline \multirow{4}{*}{ Ivory Coast } & \multirow{3}{*}{ Plantation A } & 2002 & Forecasting & Not determined & 399 & 12 & 4798 \\
\hline & & 2007 & Forecasting & 1500 & 1269 & 15 & 19035 \\
\hline & & 2009 & Systematic & 1520 & 116 & 34 & 3944 \\
\hline & Plantation B & 2007 & Forecasting & 1388 & 95 & 12 & 1140 \\
\hline \multirow{2}{*}{ Cameroon } & \multirow{2}{*}{ Plantation C } & 2005 & Systematic & 2700 & 152 & 44 & 6688 \\
\hline & & 2009 & Systematic & 3112 & 846 & 46 & 38916 \\
\hline \multirow{3}{*}{ Belize } & \multirow{2}{*}{ Plantation $\mathrm{D}^{1}$} & 2006 & Systematic 1 & 3240 & 746 & 52 & 38792 \\
\hline & & 2006 & Systematic 2 & 3240 & 378 & 50 & 18900 \\
\hline & Plantation E & 2006 & Systematic 2 & 3130 & 131 & 47 & 6157 \\
\hline
\end{tabular}

\subsection{Definition of acceptable disease thresholds}

The banana industry could probably endure a certain disease level instead of a headlong pursuit of perfect control through an increasing chemical use.

In this way, experimental deleafing of bananas has shown that bunch weight, the first component of yield, is poorly affected as long as 5 to 7 leaves remain on the banana plant from flowering to harvest [6, 43-46]. However, the effect of strong deleafing after flowering, which has been poorly studied, could probably be important since (i) fruit size is determined by the intensity of cellular divisions which occur 350 degreedays (dd) after flowering, and (ii) the rate of dry matter accumulation in fruit depends on the source-sink ratio from the end of cellular divisions to harvest [47]. Lastly, banana is a ratoon crop and the next sucker mobilizes a part of the dry matter during bunch feeding [48], so a lack of resources during this phase (as a consequence of severe spotting) could compromise the yield of the next ratoon [49]. Acceptable disease thresholds should be determined through the modelization of the effects of BLSD on bunch mass.
Such models should rely on a better understanding of disease effect on dry matter accumulation at different phenological stages and on the differential mobilization of resources by the different organs at these different stages. Since banana is a semi-perennial crop, such models should integrate successive crop cycles.

The second component of yield, the greenlife, depends on the stage of fruit maturity at harvest, which is determined by thermal sums from flowering to harvest [50]. Where no stress alters bunch feeding, bananas harvested at 900 dd reach a grade compatible with market standards [51] and a greenlife satisfactory for shipment [50]. It has been shown that abiotic stresses alter fruit growth, but have no influence on the greenlife of bananas harvested at a constant physiological age [52]. Nevertheless, it has been shown recently that biotic stresses with the intensity of Sigatoka Disease or Black Leaf Streak Disease damage significantly reduce the greenlife of bananas harvested at a constant physiological age [53, 54], arguing for a direct effect of these foliar diseases on fruit physiology by mechanisms that remain to be discovered. So, specific mechanisms of interactions between 
leaf spotting and greenlife reduction should be better understood in order to modelize the effect of BLSD on greenlife according to the harvest stage.

This global approach for BLSD on the various components of yield will enable the optimization of bunch weight according to a fixed stage of harvest (through agronomic practices), and vice versa.

\subsection{Limitation of fungicide use}

The forecasting strategies enable BLSD control with a limited use of chemicals. In such strategies, the cost of control is lower but, above all, the environmental impact is limited. Such strategies should be preferred to systematic strategies that are conducive to significant environmental impact and they should be combined with other measures such as sanitation (deleafing), drainage, under-cover irrigation and good fertilization practices. Forecasting strategies have faced some drawbacks in some countries, especially in Cameroon, because of the emergence of fungicide resistance to systemic fungicides. Nevertheless, such strategies should be implemented in specific conditions that are encountered in the banana industry: (i) banana areas free of fungicide resistance and particularly those where adverse climatic conditions exist during a part of the year (dry season). This is the case in some parts of Ivory Coast, Ghana and, probably, in some regions of Latin America (the Dominican Republic, for instance). (ii) New countries devoted to the banana industry; this is, for instance, the case of Ghana but also Mozambique and Angola, where only Sigatoka Disease is reported. When new plantations are established in new areas of a country where fungicide resistance is present, special attention should be paid to germplasm movement in order to prevent the introduction of resistant strains through planting material. This is, for instance, the case in Cameroon and Ivory Coast.

In such situations, the sustainability of the forecasting strategy would be a significant challenge. From former unsuccessful stories, we should remember that systemic fungicides should not be applied on high effective population sizes and such strategies should be interrupted when disease level is too high in order to avoid fungicide resistance. In such conditions, a temporary use of contact fungicides could decrease inoculum levels before going back to the forecasting strategy.

Lastly, where fungicide resistance is established, some data show that the interruption of systemic fungicide use can lead to a decrease in fungicide resistance [33, 40]. This decrease could result from (i) gene flow between unsprayed and sprayed plantations, and (ii) resistance cost. The acceleration of such evolution combined with incoming systemic fungicides with a new mode of action could therefore enable the reintroduction of a forecasting strategy. Such fungicide resistance management strategies should rely on a better understanding of (i) gene flow between unsprayed and sprayed areas; (ii) selection pressures, and (iii) competitiveness of resistant strains [33, 55].

\subsection{Introduction of resistant varieties into the agrosystem}

Only Cavendish bananas, highly susceptible to BLSD, are grown in the banana industry, but resistant banana cultivars exist and two types of resistance have been described [3]. The first one is a high resistance characterized by the blockage of symptoms at early stages. This type of resistance is considered to be a hypersensitive reaction of the host [56] and is found in cultivars such as Yangambi $\mathrm{km} 5$ (AAA, Ibota) and in different diploids used in breeding programs as a source of resistance (Paka, AA). The second one is a partial resistance characterized by a slower evolution of disease symptoms as compared with susceptible varieties. This type of resistance is characteristic of cultivars belonging, for example, to the subgroups Pisang Awak (ABB, i.e., Fougamou) and Mysore (AAB). Two examples suggest a potential adaptation of $M$. fijiensis on resistant cultivars:

- The first one is the observation of virulent strains of $M$. fijiensis on Paka in the Cook Islands [57]. These authors consider that these strains are widespread in the Pacific Islands and also mention that they are 
virulent on Yangambi $\mathrm{km} 5$ which is also considered as highly resistant to BLSD.

- The second one results from the release of FHIA 18 and FHIA 21, two partially resistant cultivars that have been grown over 18000 ha in Cuba. In 2003, 10 years after the introduction of these cultivars into the central region of Cuba, an increase in disease expression has been reported and aggressiveness changes in the fungal population have been suspected [58]. Nevertheless, this evolution could reflect changes in host-pathogen interactions due to environmental factors (mineral nutrition, effect of climatic conditions) and such adaptation of M. fijiensis to partially resistant cultivars is still not demonstrated.

Although the present organization of the banana industry is an obstacle to the diversification of banana cultivars in the commodity chain, the predominance of a unique type of susceptible cultivar is unsustainable and recourse to resistant varieties in an integrated strategy is probably the future of BLSD control. Since M. fijiensis has significant adaptation capacities, the type of resistance used should be polygenic instead of monogenic. So, it is hypothesized that partially resistant cultivars would be more durable than highly resistant cultivars. Few conventional breeding programs focus on the creation of such tolerant cultivars [59]. Partially resistant cultivars exist but their adaptation to an industry adapted for Cavendish cultivars is still problematic. However, a better understanding of the genetic basis of resistance to BLSD is needed for adequate breeding.

We hypothesize that the partial introduction of resistant cultivars into the agro-system could contribute to a decrease in epidemic development of BLSD on spatial scales that remain to be determined. However, partially resistant varieties could be introduced into agro-systems in different ways and the development of spatial epidemiological models would contribute to define the most efficient strategies on these spatial scales [60]. Lastly, models to predict potential changes for aggressiveness traits in fungal populations are also needed to define deployment strategies for durable resistance [61].

\section{References}

[1] Lescot T., La banane en chiffres : le fruit préféré de la planète, FruiTrop 140 (2006) 5.

[2] Loeillet D., Le commerce international de la banane : entre évolution et révolution, FruiTrop 129 (2005) 2-19.

[3] Jones D.R., Diseases of banana, abaca and enset, CAB Int., Wallingf., U.K., 2000.

[4] Pennisi E., Armed and dangerous, Science 327 (2010) 804-805.

[5] Fouré E., Les cercosporioses du bananier et leurs traitements. Comportement des variétés. Études de la sensibilité variétale des bananiers et plantains à Mycosphaerella fijiensis Morelet au Gabon (maladie des raies noires). I. Incubation et évolution de la maladie, Fruits 37 (1982) 749-759.

[6] Ramsey M.D., Daniells J.W., Anderson D.J., Effects of Sigatoka leaf spot (Mycosphaerella musicola Leach) on fruit yields, field ripening and greenlife of bananas in North Queensland, Sci. Hortic. 41 (1990) 305-313.

[7] Stover R.H., Effet du cercospora noir sur les plantains en Amérique centrale, Fruits 38 (1983) 326-329.

[8] Mobambo K.N., Gauhl F., Pasberg-Gauhl C., Zuofa K., Season and plant age effect evaluation of plantain for response to black sigatoka disease, Crop Prot. 15 (1996).

[9] Burg S.P., Burg E.A., Relationship between ethylene production and ripening in bananas, Bot. Gaz. 126 (1965) 200-204.

[10] Peacock B.C., Blake J.R., Some effects of non-damaging temperatures on the life and respiratory behaviour of bananas, Qld. J. Agric. Anim. Sci. 27 (1970) 147-168.

[11] Stover R.H., Banana, plantain and abaca diseases, Commonw. Mycol. Inst., Kew, Surrey, U.K., 1972.

[12] Stover R.H., Simmonds N.W., Bananas, Longman, Essex, U.K., 1987.

[13] Leach R., A new form of banana leaf spot in Fiji, black leaf streak, World Crops 16 (1964) 60-64.

[14] Zimmerman A., Über einige tropisher Kulturpflanzen beobachtete Pilze, Zentralblatt für Nakteriologie, Parasitenkunde, Infektionskrankh. Hyg. 8 (1902) 219.

[15] Meredith D.S., Lawrence J.S., Black Leaf Streak Disease of bananas (Mycosphaerella 
fijiensis): symptoms of disease in Hawaï, and notes on the conidial state of the causal fungus, Trans. Br. Mycol. Soc. 52 (1969) 459476.

[16] Carlier J., Zapater M.F., Lapeyre F., Jones D.R., Mourichon X., Septoria leaf spot of banana: A newly discovered disease caused by Mycosphaerella eumusae (anamorph Septoria eumusae), Phytopathology 90 (2000) 884-890.

[17] Arzanlou M., Groenewald J.Z., Fullerton R.A., Abeln E.C.A., Carlier J., Zapater M.F., Buddenhagen I.W., Viljoen A., Crous P.W., Multiple gene genealogies and phenotypic characters differentiate several novel species of Mycosphaerella and related anamorphs on banana, Persoonia 20 (2008) 19-37.

[18] Arzanlou M., Abeln E.C.A., Kema G.H.J., Waalwijk C., Carlier J., de Vries I., Guzman M., Crous P.W., Molecular diagnostics for the sigatoka disease complex of banana, Phytopathology 97 (2007) 1112-1118.

[19] Henderson J., Pattemore J.A., Porchun S.C., Hayden H.L., Van Brunschot S., Grice K.R.E., Peterson R.A., Thomas-Hall S.R., Aitken E.A.B., Black Sigatoka disease: new technologies to strengthen eradication strategies in Australia, Aust. Plant Pathol. 35 (2006) 181-193.

[20] Burt P.J.A., Rutter J., Gonzales H., Short-distance wind dispersal of the fungal pathogens causing Sigatoka diseases in banana and plantains, Plant Pathol. 46 (1997) 451-458.

[21] Gauhl F., Epidemiology and ecology of Black Sigatoka (Mycosphaerella fijiensis Morelet) on plantain and banana (Musa spp.) in Costa Rica, Central America, Göttingen Univ., PhD thesis, Göttingen, Ger., 1994, 120 p.

[22] Guzman M., Current situation and future perspectives of Black Sigatoka management in Latin America, XVII Acorbat Meet., 15-20 Oct., Joinville, Brasil, 2006.

[23] Fouré E., Les cercosporioses du bananier et leurs traitements. Comportement des variétés. Etude de la sensibilité variétale des bananiers et plantains à Mycosphaerella fijiensis Morelet au Gabon (maladie des raies noires), suite III, Fruits 40 (1985) 393-399.

[24] Fouré E., Lescot T., Variabilité génétique des Mycosphaerella inféodés au genre Musa. Mise en évidence de la présence au Cameroun sur bananiers et plantains d'une cercosporiose (Mycosphaerella musicola) au comportement pathogène atypique, Fruits 43 (1988) 407-415.
[25] Mouliom Pefoura A., Lassoudiere A., Foko J., Fontem D.A., Comparison of development of Mycosphaerella fijiensis and Mycosphaerella musicola on banana and plantain in the various ecological zones in Cameroon, Plant Dis. 80 (1996) 950-954.

[26] Carlier J., Lebrun M.H., Zapater M.F., Dubois C., Mourichon X., Genetic structure of the global population of banana black leaf streak fungus, Mycosphaerella fijiensis, Mol. Ecol. 5 (1996) 499-510.

[27] Mourichon X., Fullerton R.A., Geographical distribution of the two species Mycosphaerella musicola Leach (Cercospora musae) and $M$. fijiensis Morelet (C. fijiensis), respectively agents of Sigatoka disease and Black Leaf Streak disease in bananas and plantains, Fruits 45 (1990) 213-218.

[28] Rivas G.G., Zapater M.F., Abadie C., Carlier J., Founder effects and stochastic dispersal at the continental scale of the fungal pathogen of bananas Mycosphaerella fijiensis, Mol. Ecol. 13 (2004) 471-482.

[29] Halkett F., Coste D., Rivas G.G., Zapater M.F., Abadie C., Carlier J., Genetic discontinuities and disequilibria in recently established populations of the plant pathogenic fungus Mycosphaerella fijiensis, Mol. Ecol. 19 (2010) 3909-3923.

[30] Abadie C., lotti J., Teycheney P.Y., Development of surveillance networks, data exchanges and joint response strategies in the Caribbean: the French experience, 45nd Annu. Meet. Caribb. Food Crop Soc., July 12-15, 2009, Basse-Terre, St-Kitts et Nevis, Guadeloupe, Fr., 2009.

[31] Marin D.H., Romero R.A., Guzman M., Sutton T.B., Black Sigatoka: an increasing threat to banana cultivation, Plant Dis. 87 (2003) 208-222.

[32] Fouré E., Stratégies de lutte contre la cercosporiose noire des bananiers et des plantains provoquée par Mycosphaerella fijiensis Morelet. L'avertissement biologique au Cameroun. Evaluation des possibilités d'amélioration, Fruits 43 (1988) 269-274.

[33] de Lapeyre de Bellaire L., Essoh Ngando J., Abadie C., Chabrier C., Blanco R., Lescot T., Carlier J., Côte F., Is chemical control of Mycosphaerella foliar diseases of bananas sustainable? Acta Hortic. 828 (2009) 161170.

[34] McDonald B.A., Linde C., Pathogen population genetics, evolutionary potential and durable resistance, Annu. Rev. Phytopathol. 40 (2002) 349-379. 
[35] Bartlett D.W., Clough J.M., Godwin J.R., Hall A.A., Hamer M., Parr-Dobrzanski B., Review: the strobilurin fungicides, Pest Manag. Sci. 58 (2002) 649-662.

[36] Fouré E., Ganry J., A biological forecasting system to control Black Leaf Streak disease of bananas and plantains, Fruits 63 (2008) 311-317.

[37] Romero R.A., Sutton T.B., Characterization of benomyl resistance in Mycosphaerella fijiensis, cause of black Sigatoka of banana, in Costa Rica, Plant Dis. 82 (1998) 931-934.

[38] Amil A.F., Heaney S.P., Stanger C., Shaw M.W., Dynamics of Qol sensitivity in Mycosphaerella fijiensis in Costa Rica during 2000 to 2003, Phytopathology 97 (2007) 14511457.

[39] Romero R.A., Sutton T.B., Sensitivity of Mycosphaerella fijiensis, causal agent of Black Sigatoka of banana, to Propiconazole, Phytopathology 87 (1997) 96-100.

[40] Anon., Minutes of the banana working group, in: www.frac.info (Ed.), 2010.

[41] Risède J.M., Lescot T., Cabrera Cabrera J., Guillon M., Tomekpé K., Kema G.H.J., Côte F., From science to field. Banana case study - Guide number 1, Challenging short and mid-term strategies to reduce pesticides in bananas, in: ENDURE (Ed.), Montpellier, France, 2010.

[42] Stover R.H., A proposed international scale for estimating intensity of banana leaf spot (Mycosphaerella musicola Leach),Trop. Agric. 48 (1971) 185-196.

[43] Daniells J.W., Lisle A.T., Bryde N.J., Effect of bunch trimming and leaf removal at flowering on maturity bronzing, yield, and other aspects of fruit-quality of bananas in North Queensland, Aust. J. Exp. Agric. 34 (1994) 259-265.

[44] Lassois L., Bastiaanse H., Chillet M., Jullien A., Jijakli M.H., de Lapeyre de Bellaire L., Hand position on the bunch and source-sink ratio influence the banana fruit susceptibility to crown rot disease, Ann. Appl. Biol. 156 (2010) 221-229.

[45] Robinson J.C., Anderson T., Eckstein K., The Influence of functional leaf removal at flower emergence on components of yield and photosynthetic compensation in banana, J. Hortic. Sci. 67 (1992) 403-410.

[46] Vargas A., Araya M., Guzman M., Murillo G., Effect of leaf pruning at flower emergence of banana plants (Musa AAA) on fruit yield and black Sigatoka (Mycosphaerella fijiensis) disease, Int. J. Pest Manag. 55 (2009) 19-25.

[47] Jullien A., Munier-Jolain N., Malézieux E., Chillet M., Ney B., Effect of pulp cell number and assimilate availability on dry matter accumulation rate in a banana fruit [Musa sp., AAA, group 'Grande Naine' (Cavendish subgroup)], Ann. Bot. 88 (2001) 321-330.

[48] Eckstein K., Robinson J.C., Davie S.J., Physiological-responses of banana (Musa-aaa, Cavendish subgroup) in the subtropics. 3. Gas-exchange, growth analysis and source-sink interaction over a complete crop cycle, J. Hortic. Sci. 70 (1995) 169-180.

[49] Dens K.R., Romero R.A., Swennen R., Turner D.W., Removal of bunch, leaves, or pseudostem alone, or in combination, influences growth and bunch weight of ratoon crops in two banana cultivars, J. Hortic. Sci. \& Biotechnol. 83 (2008) 113-119.

[50] Jullien A., Chillet M., Malézieux E., Pre-harvest growth and development, measured as accumulated degree days, determine the post-harvest green life of banana fruit, $\mathrm{J}$. Hortic. Sci. \& Biotechnol. 83 (2008) 506-512.

[51] Ganry J., Meyer J.P., Recherche d'une loi d'action de la température sur la croissance des fruits du bananier, Fruits 30 (1975) 375392.

[52] Chillet M., Hubert O., Ribes M.J., de Lapeyre de Bellaire L., Effects of the physiological age of bananas on their susceptibility to wound anthracnose due to Colletotrichum musae, Plant Dis. 90 (2006) 1181-1185.

[53] Abadie C., Hubert O., Ngando Essoh J., Ngoh G., Mbéguié-A-Mbéguié D., de Lapeyre de Bellaire L., Chillet M., Evidence of the effects of Mycosphaerella leaf spot diseases on fruit quality, in: Borja J.S., Orrantia C., Paladines R., Quimí V., Tazán L. (Eds.), XVIIIth ACORBAT Meet., 10-14 November 2008, Guayaquil, Ecuador, 2008.

[54] Chillet M., Abadie C., Hubert O., ChilinCharles Y., De Lapeyre de Bellaire L., Sigatoka disease reduces the greenlife of bananas, Crop Prot. 28 (2009) 41-45.

[55] de Lapeyre de Bellaire L., Rieux A., Ngando Essoh J., Zapater M.F., Carreel F., Ravigne V., Carlier J., An integrated approach to define management strategies of fungicide resistance in populations of the plant pathogenic fungus Mycosphaerella fijiensis, in: Bertrand J.C., Bonis A., Caquet T., Franc A., Garnier E., Olivieri I., Thébaud C., Roy J. 
(Eds.), Ecologie 2010, Montpellier, France, 2-4 Sept., 2010, P02/05, p. 252.

[56] Beveraggi A., Mourichon X., Salle G., Comparative study of the first stages of infection in sensitive and resistant banana plants with Cercospora fijiensis (Mycosphaerella fijiensis), responsible for Black Leaf Streak Disease, Can. J. Bot. 73 (1995) 1328-1337.

[57] Fullerton R., Olsen T., Pathogenic variability in Mycosphaerella fijiensis Morelet cause of black Sigatoka in banana and plantain, N. Z. J. Crop Hortic. Sci. 23 (1995) 39-48.

[58] Perez-Vicente L., Alternative management of Black Sigatoka caused by Mycosphaerella fijiensis Morelet in bananas and plantains, in: Soprano E., Tcacenco F.A., Lichtemberg
L.A., Silva M.C. (Eds.), XVIlth Acorbat Int. Meet., 15-20 Oct. 2006, Joinville, Brasil, 2006.

[59] Abadie C., Chilin-Charles Y., Huat J., Salmon F., Pignolet L., Carlier J., Lescot T., Côte F., Jenny C., New approaches to select cultivars of banana with durable resistance to Mycosphaerella leaf spot diseases, Acta Hortic. 828 (2009) 171-178.

[60] Gilligan C.A., Sustainable agriculture and plant diseases: an epidemiological perspective, Phil. Trans. R. Soc. 363 (2008) 741-759.

[61] Pariaud B., Ravigné V., Halkett F., Goyeau H., Carlier J., Lannou C.,. Aggressiveness and its role in the adaptation of plant pathogens, Plant Pathol. 58 (3) (2009) 409-424.

\section{La enfermedad de las rayas negras desafía a la industria de la banana.}

Resumen - Introducción. La enfermedad de las rayas negras (ERN) es la amenaza más grande a la cual se enfrenta la industria de la banana. Efectivamente, dicha enfermedad foliar afecta la fotosíntesis de los bananos, pero, sobre todo, conlleva una reducción del potencial de conservación de los frutos que no pueden exportarse cuando los bananos están severamente afectados. Principales características de la ERN. Se describieron en el banano más de 20 especies del género Mycosphaerella, pero las cercosporiosis de los bananos son principalmente el resultado de dos especies $M$. fijiensis (ERN) y M. musicola (enfermedad de Sigatoka). M. fijiensis es una especie invasiva que remplazó totalmente a $M$. musicola en la mayor parte de los países exportadores de bananos, lo que siempre se tradujo por un control más difícil de la cercosporiosis. Dificultades de control crecientes. Dado a que todas las variedades de bananos cultivados en la industria de la banana son muy sensibles a las cercosporiosis, el control de la ERN se basa en la aplicación aérea de fungicidas, tanto según programas sistemáticos (fungicidas de contacto), como por prevención (fungicidas sistemáticos). En los países exportadores de bananos donde se detectó $M$. fijiensis, el control de la ERN se ha vuelto cada vez más difícil. Dicha evolución se debe principalmente a la aparición de cepas resistentes a los fungicidas y se tradujo por un aumento del coste de la lucha, pero sobre todo por un incremento de los impactos medioambientales. Desafios para la industria bananera. Dado a que $M$. fijiensis posee capacidades de adaptación muy rápida, una de las condiciones de supervivencia de la industria bananera es la preparación a importantes mutaciones. Proponemos un conjunto de indicadores de diferentes niveles (parcela, eficacia general de la lucha, incidencia económica general) con el fin de objetivar estas evoluciones. La modelización de los efectos de la ERN en el peso de los regímenes y la duración de conservación de los frutos debería permitir definir los niveles de enfermedad aceptables. Debería asimismo permitir optimizar el peso de los regímenes y el estado de cosecha en función de las prácticas agronómicas. De modo a limitar el uso de los fungicidas que tienen un impacto medioambiental importante, las estrategias de prevención deben emplearse ahí donde los fungicidas sistemáticos aún son eficaces. Por último, el predominio de cultivares sensibles no es duradero y el futuro de esta industria pasa probablemente por la incorporación de variedades resistentes en los sistemas de cultivo.

Francia / Musa / control de enfermedades / enfermedades fungosas / Mycosphaerella fijiensis / resistencia a productos químicos 